\title{
Maimonides on Predication and Divine Language
}

\author{
Jakub Ráliš
}

This paper is primarily aimed as a setting up of the controversial yet in some authoritative secondary literature established interpretation of Maimonidean theory of predication and problem tied to it. ${ }^{\mathrm{i}}$ In footnotes there are most important paginations for the given premises and should be treated as integral part of the argumentation, which for the sake of readability are sometimes not included inside the text itself. On the other side for the reason of relative strangeness of Maimonidean corpus especially among the researcher on the field of Greek and Latin tradition I will use more extensive essentials quotations from Maimonides straight in the text and Maimonides himself is often very clear.

Divine language and predication to God is topic so frequent in medieval philosophy that we cannot overstate its importance. It is obvious then that most important Jewish thinker of medieval period had a lot to say about it and almost as always his solution and view could be described as entirely original, at least in Jewish philosophical environment. In this paper we will try to sketch very rifly but also thoroughly source-wise basis of his conception and also very deep philosophical problems connected of his views. We will just uncover

\footnotetext{
' See for example Rudavsky, Maimonides, Willey-Blackwell, 2011, p. 36- 50.
} 
these problems and leave them open for "readers" as was the custom and aim of Maimonides himself. Most interesting and important on this topic is that in this basis research we will not only shed light on the Maimonidean conception of predication and language, but through that we will see clearly his highly distinct view of highest deity as Aristotelian "God of philosophers" much more that biblical "God of Abraham".

Maimonides tried to provide detailed and accurate image of God according to his understanding in many chapters of his work. I will look especially into the one particular point that was found radical and echoed not only in Jewish philosophical tradition. The topic could be summarized as "how do we talk about god?" To clarify my starting position in the very beginning my reading of mentioned passages and understanding of the whole problem could be basically described as a middle position between famous Pines interpretations and those of Kellner or Manekin ${ }^{i}$ especially in the case of affirmative predication. I will dodge Maimonides more intricate proofs of existence ${ }^{\mathrm{ii}}$ i.e. question if

\footnotetext{
'Pines' interpretation stirred the waters of Maimonidean scholar ship in the 1980 '. He basically argued that Maimonides hold strong philosophical conception fo God where there is no place for revealed rules of Torah and God of Judaism. See Pines, S. and Yovel, Y. (eds.) Maimonides and Philosophy. Dordrecht: M. Nijhoff, 1985. Whereas interpretations of Kellner or Manekin are attempting to „save“ Maimonides or at least his philosophy for Judaism.

See Kellner Menachem, Dogma In Medieval Jewish Philosophy. New York: Oxford University Press, 1986; Manekin, Charles, On Maimonides. Belmont, CA.: Wadsworth, 2005.

ii Argument for the existence of God itself is one of the hotspots of Maimonidean interpretation. For our purpose is not necessary to solve this problem. Generally it is shown on this topic the difference between Aristotelian and Jewish Cosmogony and it is also central topic for the alleged Maimonides esoteric writing. For the problem of existence argument see for example: Tamas Visi: The Existence of God: Maimonides ' Intricate Argument. Saarbrücken: VDM Verlag Dr. Müller, 2008
} 
the god is, which are "only" variations on the cosmological argument as always.

I will focus on the problem of predication to God, in broader picture it means if could we know what god is and how do we talk about him. ${ }^{i}$ Although any interpretation of Maimonides work always opens evergreen question about understanding of Maimonides' work as a whole. i.e. his use of noble lie, exoteric vs esoteric ${ }^{\text {ii }}$ writing and his "true" opinions displayed or hidden in Guide of the Perplexed ${ }^{\mathrm{iii}}$, although problem of esoteric and exoteric writing was long time debated basically since the 14th century. Throughout the centuries it was certainly central topic for many Maimonidean scholar - What is the „real“ meaning of Maimonides philosophical writing, this problem was brought to wider attention by Leo Strauss in 1952 in his books Persecution and the Art of Writing. There he argues that Maimonides same as other famous authors (Plato, Spinoza) used esoterical way of writing in order to conceal opinions (no matter if strictly speaking his) that could be by the public and authorities perceived as dangerous and noxious and could bring punishment on the head of the author.

In this respect esoteric means - as in original sense of meaning something for ,inner circle“, something hidden. And exoteric writing for "outer circle" aimed for the general public. This conception of course

\footnotetext{
${ }^{\mathrm{i}}$ More precisely how do we attribute to God any predicates at all and is it possible to use natural language in respect to Gods essence and even attributes?

ii See Strauss, Leo, "The literary Character of the Guide for the Perplexed," in Persecution and the Art of Writing. Glencoe, IL, The Free Press, 1952.

iii I am most of the time using English editions of Schwarz and Pines:

Schwarz, M (tr.) More Nevukhim. Tel Aviv: Tel Aviv University Press, 2002.

[GP] Pines, S. (tr.) The Guide of the Perplexed. Chicago: University of Chicago Press, 1963.
} 
work best with Plato's dialogues, but for Maimonidean philosophy is by some taken as either refuted or problematic. These fortunately are not essential troubles for our talk because problems mentioned below are stated by Maimonides quite explicitly in his work and are mainly concentrated in the first part of his Guide of the Perplexed whereas problems with esoteric writing and doctrines are mostly connected to the later parts dealing with existence of god and eternality of the cosmos. ${ }^{\text {i }}$ Concerning the existence of God Maimonides thinks (at least in traditional interpretation) that cosmological argument he uses in Mishne Torah $^{\mathrm{ii}}$ and Guide of the Peplexed gives us sufficient proof for saying that God is, but not What God is. To see why not, we have to recognize that God's oneness or anything else is not in any way comparable to anything else: one person, one number, one idea. In Guide of the Perplexed 1.51 he says:

There is no oneness at all except in believing that there is one simple essence in which there is no complexity or multiplicity of notions, but one notion only. ${ }^{\mathrm{ii}}$

According to Maimonides there can be no plurality of faculties, moral

\footnotetext{
${ }^{\mathrm{i}}$ One of the main problems for Maimonides - externality of Aristotelean Cosmos and creatio ex nihilo - concept strongly connected to Jewish thinking. Further see Seeskin, Kenneth Maimonides on the Origin of the World. New York: Cambridge University Press, 2005.

ii Sefer Yad HaHazaka is Maimondes' main rabbinical writing and it is obviously aimed at the public we can and will use it for the cross-referencing of the problem of equivocality. Important fact is that in the Mishne Torah we cannot presupposed some kind of esoterical or hidden writing and therefore $\mathrm{i}$ tis not important to search for some deeper level of understanding.

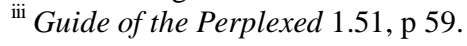


dispositions, or essential attributes in God. Even to say that God is allknowing, all-powerful, and all-good is to introduce plurality. The same is true if we say that God is a composite of matter and form, genus or essence and accident. To quote Seeskin: "All introduce plurality where none can be tolerated."

Maimonides then argues that we cannot attribute to God any predicates that imply any anthropomorphic or corporeal features to him at all. We shall see that according to Maimonides very little if anything at all can be said about God. Maimonides persistently argues that god is not a body and incorporeality truly is the main feature of his conception of God. It is important to understand that in Islamic and Jewish environment which surrounded Maimonides was acceptance of god corporeality deeply rooted and that is probably the reason why he devoted so much effort to the fight against it.

Throughout his works it is emphasizes that incorporeality and unity of Deity must be taught to all. Already in his rabbinical writings Maimonides claims that phrases about corporeal nature of deity in Scripture like "beneath his feet" in the the eyes of god" God wrath etc. are " adapted to the mental capacity of the majority of mankind who have clear perception of physical bodies. ${ }^{\text {ii }}$ Torah simply uses language appropriate to the individuals and they must be understood metaphorically (concept very well known to us but not so to 12th century reader). And in the first place incorporeality in Maimonides understanding means that we cannot attribute any accidents of matter to god and therefore he does not exist in time nor he does change or have

\footnotetext{
i Seeskin, Kenneth, "Maimonides", The Stanford Encyclopedia of Philosophy (Spring 2014 Edition), Edward N. Zalta (ed.)

${ }^{\text {ii }}$ HYT 1. 34b.
} 
any emotions. ${ }^{\mathrm{i}}$

In Guide of the Perplexed he again maintains that following characteristics must be taught to everyone without exception: that god is one, there is none like god, god is not a body and god has no likenesses in his creation in any way. Because corporeality of god was as I mentioned deeply engraved in Jewish tradition and that why Maimonides devotes basically whole first part of the first book of Guide of the Perplexed to the construction of the new image of incorporeal god in scripture through metaphorical reading God's incorporeality and otherness must be in the first place reflected in the language.

In famous 1.51.- 60 he elaborated his theory of predicting which could be perceived as a radical even from the viewpoint of his Arabic predecessors. Our interest lies primarily in the chapter $56 .{ }^{\mathrm{ii}}$ Let us look at the core of the texts which is usually seen as a key to understanding of Maimonides conception of predication:

You must know that two things of the same kind--i.e., whose essential properties are the same, and which are distinguished from each other by greatness and smallness, strength and weakness, etc.--are necessarily similar, though different in this one way; e.g., a grain of mustard and the sphere of the fixed stars are similar as regards the three dimensions, although the one is exceedingly great, the other exceedingly small, the property of having [three] dimensions is the same in both: or the heat of wax melted by the sun and the heat of the element of fire, are similar as

\footnotetext{
${ }^{\mathrm{i}}$ Guide of the Perplexed 1.11, Friedländer translation.

${ }^{\text {ii }}$ Chapters 56 and 57 are mostly dealing with their likenesses of God, which are according to Maimonides ,absolutely Other" than ours.
} 
regards heat: although the heat is exceedingly great in the one case, and exceedingly small in the other, the existence of that quality (heat) is the same in both. Thus those who believe in the presence of essential attributes in God, viz., Existence, Life, Power, Wisdom, and Will, should know that these attributes, when applied to God, have not the same meaning as when applied to us, and that the difference does not only consist in magnitude, or in the degree of perfection, stability, and durability. It cannot be said, as they practically believe, that His existence is only more stable, His life more permanent, His power greater, His wisdom more perfect, and His will more general than ours, and that the same definition applies to both. ${ }^{i}$

It's hard or impossible to talk about god. Firstly because his incorporeality and also because applying any attributes to god's essence would mean intrusion into god oneness or rather otherness. He goes even further: even to ascribe God the accident of oneness is " just as absurd as to ascribe him the accident of multiplicity" ii In other words: of the various types of affirmative attributes only homonyms are somehow representing God according to Maimonides.In Guide he states on this topic:

Those who are familiar with the meaning of similarity will certainly understand that the term existence, when applied to God and to other beings, is perfectly homonymous. In like manner, the terms Wisdom, Power, Will, and Life are applied to God and to other beings by way of

\footnotetext{
${ }^{\mathrm{i}}$ Guide of the Perplexed 1.56, p. 79

${ }^{\text {ii }}$ Guide of the Perplexed 1.57
} 
perfect homonymity, admitting ${ }^{i}$

We predicate essential proposition like the four basic attributes of god: life power wisdom and will, but even these, when use in respect to god, are used just in equivocal (homonymous) sense. In his Treatise on the Art of Logic ${ }^{i i}$ based on Aristotle's Topics he distinguished three types of terms:

Univocal, amphibolous and equivocal or homonymous, where univocal term means:

A term is used univocally when there is something which constitutes the essence of two or more things, and that term refers to each one of these things that share in that constitutive essence; e. g., the term 'animal', which is applied to man, horse, scorpion, and fish, because life which is nourishability is found in each one of these species and constitutes its essence. Thus, the name of any genus is applied to its component species univocally, and every specific difference is applied to all the individuals of the species univocally. ${ }^{\text {iii }}$

Then Maimonides describes amphibolous as follows:

\footnotetext{
${ }^{\mathrm{i}}$ Guide of the Perplexed 1.56, p. 79.

${ }^{\text {ii }}$ Although it is disputed if authorship of this work could be ascribed to Maimonides. For example Davidson, Moses Maimonides (2005), p. 313-318 takes this short treatise a misattributed. He argues that because of stylistics and also simple fact that there are at least two manuscripts where there is nowhere to be found name of Maimonides, we should suppose that he is not the author. On the other side mostly translator as Joseph Ibn Vives, R. Brague (1996) takes these to be work of Maimonides.

iii See Treatise on the Art of Logic, p. 59.
} 
But the amphibolous term is a term applied to two or more objects because of something which they have in common but which does not constitute the essence of each one of them. An example of this is the name 'man' given to Reuben, the rational animal, to a certain man who is dead, and to an image of man carved in wood or painted. This name is applied to them because of their having one thing in common, to wit, the figure and outline of a man; but the figure and outline do not constitute the meaning of man. Hence it resembles a univocal term in so far as it is applied to these objects because they have something in common, and it also resembles the absolute homonym because the essence of one is different from that of the other. It is therefore called amphibolous. ${ }^{\mathrm{i}}$

Maimonides then argues that predicates attributed to god can't be neither univocal or amphibolous, because, as we emphasized earlier, there is NO common ground between god and human (or even his creations) This is the reason why predicated terms of God we are using must, be understood only in the equivocal sense. All the predicates then, including even the term power, life, will and knowledge, have "nothing common in any respect or in any mode; these attributions have in common only the name and nothing else." ${ }^{\text {,ii }}$ For Maimonides are most important so called absolute homonym:

The absolute homony is one applied to two things, between which there is

\footnotetext{
${ }^{\mathrm{i}}$ See Treatise on the Art of Logic, p. 60.

${ }^{\text {ii }}$ Guide of the Perplexed 1.56131.
} 
nothing in common to account for their common name, like the name 'ain signifying an eye and a spring of water, and like the name keleb (dog) applied to the star and to the animal. ${ }^{i}$

Maimonides then stresses in 1.59 that only absolute homonymous prediction captures the fact that God has no essential or accidental characteristic in common with his creation. God is absolutely other in all respects.

You must bear in mind, that by affirming anything of God, you are removed from Him in two respects; first, whatever you affirm, is only a perfection in relation to us; secondly, He does not possess anything superadded to this essence; His essence includes all His perfections, as we have shown. Since it is a well-known fact that even that knowledge of God which is accessible to man cannot be attained except by negations, and that negations do not convey a true idea of the being to which they refer, all people, both of past and present generations, declared that God cannot be the object of human comprehension, that none but Himself comprehends what He is, and that our knowledge consists in knowing that we are unable truly to comprehend Him. ${ }^{i i}$

All we say about him has only imaginative similarity through name. No attributes can be then truly ascribed to god and nothing could be really said about god. If this is true it is at least very interesting position among

\footnotetext{
i Treatise on the Art of Logic, p. 59.

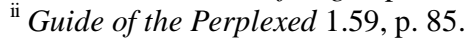


the Jewish Thinkers.

But then how do we talk about god at all? We are left with entity that can't be known or described properly in human language. By using our language and ascribing God terms that cannot touch his transcendent nature, we are actually "insulting" the God's true essence. For Maimonides are possibilities how to say anything about god or to approach him through language very narrow indeed. Only way is negation of the privation based again on Aristotle's logic. For example: applying temporality of non- temporality would be again categorical error and then only way how to emphasize the unique nature of god is to say "God is not-un-temporal". Therefore we have to use "negation of privation of the attribute in question." (1.58.136). Even if we take in account problematic character of authorship of Tretise on the Art of Logic, this passage still usually serves as a very strong evidence for Maimonides equivocal conception of God.

Maimonides is strict about ascribing positive attributes to god, for such an action actually recess us from god's true nature and although negation of privation could be the way how to use our language in respect to god, ultimately silence is only proper response to divine prediction. In 1.59.Maimonides concludes this part with famous quotation:

Much more has been said on this topic, but it is useless to repeat it here. The idea is best expressed in the book of Psalms, "Silence is praise to Thee" (lxv. 2). It is a very expressive remark on this subject; for whatever we utter with the intention of extolling and of praising Him, contains something that cannot be applied to God, and includes

\footnotetext{
${ }^{\mathrm{i}}$ Guide of the Perplexed 1.58, p 83.
} 
derogatory expressions; it is therefore more becoming to be silent, and to be content with intellectual reflection, as has been recommended by men of the highest culture, in the words "Commune with your own heart upon your bed, and be still" (Ps. iv. 4). ${ }^{i}$

Although some scholars tried to soften the edges and save Maimonides for the traditions Judaism ${ }^{\mathrm{ii}}$ ), explicit nature of Maimonides linguistic analysis and approach to god's otherness cannot be dismissed or marginalized. We are left with very philosophical image of almost completely transcendent entity that could be praised just by silence and awe over so called action attributes.

In my opinion this radical linguistic theory of Maimonides could be taken as one of the absolutely key elements to understanding Maimonides corpus as a whole. But, as we can tell from his letters, Maimonides was always political and social realist and he later in Guide of the Perplexed $d^{\mathrm{iii}}$ acknowledges that system of religion based only on silence could not be successful and therefore we could (and must pray ${ }^{\text {iv }}$ ) as long as we understand that such prayers leaves god un-described and unknowable.

Could we not understand series of these statements as a noble lie by the philosopher king? Who on the one site knows the truth i.e. the

\footnotetext{
${ }^{\mathrm{i}}$ Guide of the Perplexed 1.59 , p. 86.

${ }^{\text {ii }}$ Manekin, Seeskin, Altman - Are using switch in interpretation in order to save "Maimonidean God" from the trap of absolute unknowability and impossibility of payer and therefore effective crush of revealed religion. They are then arguing that Maimonides had in mind inexplicability rather the unknowability. In this interpretation we can attribute predicates of God and they even have some likenesses in the sense of quality but are absolutely other in the sense of quantity.

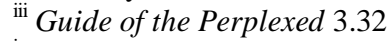

iv It is stated explicitly in Misne Torah 2.2 and On the Prayers 1.1.
} 


\section{AlOHP}

absolute otherness of God, but on the other understand the social dangerousness of such idea in Medieval context and therefore wisely decided that ritual, tradition and language based religion is necessity, at least for non philosophers. ${ }^{\text {i }}$

${ }^{\mathrm{i}}$ This articles was prepared under the funding from Palacky Universtiy Grant reg. no. FF_2013_065 - Věda v aristotelské tradici. 